medRxiv preprint doi: https://doi.org/10.1101/2020.03.18.20038133; this version posted March 20, 2020. The copyright holder for this preprint (which was not certified by peer review) is the author/funder, who has granted medRxiv a license to display the preprint in All rights reserved. No reuse allowed without permission.

\title{
Comparison of the coronavirus pandemic dynamics in Europe, USA and South Korea
}

\author{
Igor Nesteruk
}

Institute of Hydromechanics, National Academy of Sciences of Ukraine, Zheliabova 8/4, UA-03680 Kyiv, Ukraine

National Technical University of Ukraine "Igor Sikorsky Kyiv Polytechnic Institute", Prosp.Peremohy 37, UA-03056, Kyiv, Ukraine.

inesteruk@yahoo.com

\begin{abstract}
The pandemic cased by coronavirus COVID-19 is of great concern. A detailed scientific analysis of this phenomenon is still to come, but now it is urgently needed to evaluate the disease dynamics in order to organize the appropriate quarantine activities, to estimate the required number of places in hospitals, the level of individual protection, the rate of isolation of infected persons, etc. South Korea has achieved the stabilization of the number of cases at rather low level. The epidemic dynamics there can be compared with its development in other countries to make some preliminary, but very important conclusions. Here we provide a simple method of data comparison that can be useful for both governmental organizations and anyone.
\end{abstract}

Key-words. coronavirus COVID-19 pandemic, coronavirus COVID-19, coronavirus 2019-nCoV, mathematical modeling, statistical methods.

\section{Introduction}

Some previous efforts to compare the epidemic dynamics in Italy and mainland China has been done in $[1,2]$. Here we will try to compare the epidemics in Italy, Spain, Germany, France, Switzerland, and USA with the situation in South Korea, where the number of cases is stabilizing at rather low level and the mortality rate is not high. We improved the very simple method proposed in [1] which now can by applied for every country. To illustrate its application, the epidemic dynamics in Austria was estimated.

\section{Data}

NOTE: This preprint reports new research that has not been certified by peer review and should not be used to guide clinical practice.

We will use official data about the accumulated number of confirmed cases in Italy, Spain, France, Germany, Switzerland, USA, South Korea $V_{j}$ from WHO daily situation reports [3], see 
medRxiv preprint doi: https://doi.org/10.1101/2020.03.18.20038133; this version posted March 20, 2020. The copyright holder for this preprint (which was not certified by peer review) is the author/funder, who has granted medRxiv a license to display the preprint in perpetuity.

All rights reserved. No reuse allowed without permission.

Tables 1 and 2. Since the reports show the numbers accumulated by 10AM CET, we assumed that every number $V_{j}$ corresponds to the previous day. The values $V_{j}$ and corresponding moments of time $t_{j}$ and $t_{e j}$ are shown in Tables 1 and 2.

\begin{tabular}{|c|c|c|c|c|c|}
\hline $\begin{array}{l}\text { Day in } \\
\text { February, } \\
2020\end{array}$ & $\begin{array}{l}\text { Time } \\
\text { moment } \\
t_{j}\end{array}$ & $\begin{array}{l}\text { Accumulated } \\
\text { number of cases } \\
\text { in the Republic } \\
\text { of Korea } V_{j}, \text { [3] }\end{array}$ & $\begin{array}{l}\text { Day in } \\
\text { March, } \\
2020\end{array}$ & $\begin{array}{l}\text { Time } \\
\text { moment } \\
t_{j}\end{array}$ & $\begin{array}{l}\text { Accumulated } \\
\text { number of cases } \\
\text { in the Republic of } \\
\text { Korea } V_{j},[3]\end{array}$ \\
\hline 17 & -1 & 31 & 1 & 12 & 4212 \\
\hline 18 & 0 & 51 & 2 & 13 & 4812 \\
\hline 19 & 1 & 104 & 3 & 14 & 5328 \\
\hline 20 & 2 & 204 & 4 & 15 & 5766 \\
\hline 21 & 3 & 346 & 5 & 16 & 6284 \\
\hline 22 & 4 & 602 & 6 & 17 & 6767 \\
\hline 23 & 5 & 763 & 7 & 18 & 7134 \\
\hline 24 & 6 & 977 & 8 & 19 & 7382 \\
\hline 25 & 7 & 1261 & 9 & 20 & 7513 \\
\hline 26 & 8 & 1766 & 10 & 21 & 7755 \\
\hline 27 & 9 & 2337 & 11 & 22 & 7869 \\
\hline 28 & 10 & 3150 & 12 & 23 & 7979 \\
\hline 29 & 11 & 3736 & 13 & 24 & 8086 \\
\hline - & - & - & 14 & 25 & 8165 \\
\hline
\end{tabular}

Table 1. Official cumulative numbers of confirmed cases in the Republic of Korea

The information from [3]. The corresponding time moments $t_{j}$ and the accumulated confirmed numbers of cases $V_{j}$ in South Korea. 
medRxiv preprint doi: https://doi.org/10.1101/2020.03.18.20038133; this version posted March 20, 2020. The copyright holder for this preprint (which was not certified by peer review) is the author/funder, who has granted medRxiv a license to display the preprint in

All rights reserved. No reuse allowed without permission.

\section{Day in February and March, 2020}

Italy 76

23

24

25

26

27

28

29

1

2

$3 \quad 2502$

$4 \quad 3089$

$5 \quad 3858$

64636

$7 \quad 5883$

$8 \quad 7375$

9

10

11

12

13

14

9172

10149

12462

15113

17660

21151

\section{Germany}

16

16

16

18

21

26

57

100

129

157

196

262

534

639

795

1112

1139

1296

1567

2369

3062

3795

\section{France}

12

12

12

12

18

38

57

57

100

191

212

282

420

613

706

1116

1402

1774

2269

2860

3640

4469

\section{Spain}

2

2

2

2

12

25

32

45

45

114

151

198

257

374

430

589

1024

1639

2140

2965

4231

5753

$\begin{array}{crc}\text { Switzerland } & \text { USA } & \boldsymbol{t}_{\boldsymbol{e}} \\ 0 & 35 & 0 \\ 0 & 35 & 1 \\ 0 & 53 & 2 \\ 1 & 53 & 3 \\ 1 & 59 & 4 \\ 6 & 59 & 5\end{array}$

$10 \quad 62 \quad 6$

$\begin{array}{lll}18 & 62 & 7\end{array}$

$24 \quad 62 \quad 8$

$\begin{array}{lll}30 & 64 & 9\end{array}$

$\begin{array}{lll}37 & 108 & 10\end{array}$

$56 \quad 129 \quad 11$

$\begin{array}{lll}86 & 148 \quad 12\end{array}$

$209 \quad 213 \quad 13$

$264 \quad 213 \quad 14$

$\begin{array}{lll}332 & 213 & 15\end{array}$

$\begin{array}{lll}332 & 472 \quad 16\end{array}$

$\begin{array}{lll}491 & 696 & 17\end{array}$

$645 \quad 987 \quad 18$

$\begin{array}{lll}858 & 1264 & 19\end{array}$

$1125 \quad 1678 \quad 20$

$1359 \quad 1678 \quad 21$

Mortality rate (\%),

March 14, 2020

$\begin{array}{rrrrrrr}6.81 & 0.21 & 2.04 & 2.36 & 0.81 & 2.44 & - \\ 0.549 & 0.154 & 0.154 & -0.179 & 0.129 & 0.312 & -\end{array}$

$d_{t}$

0.549

0.154

$0.154-0.179$

$0.129 \quad 0.312$

Table 2. The number of cases in Italy, Spain, France, Germany, Switzerland and USA used for comparisons and the results of calculations.

The information about the confirmed accumulated number of cases from [3]. The mortality rate was calculated with the use of numbers for March 14, 2020 (the situation report dated March 16, 2020, [3]). The corresponding time moments $t_{e j}$ are shown in the last column. The values corresponding the beginning of the epidemic outbreak are shown in red. The values $d_{t}$ were calculated with the use of formula (2). 
medRxiv preprint doi: https://doi.org/10.1101/2020.03.18.20038133; this version posted March 20, 2020. The copyright holder for this preprint (which was not certified by peer review) is the author/funder, who has granted medRxiv a license to display the preprint in All rights reserved. No reuse allowed without permission.

\section{Time synchronization procedure}

We have to calculate the number of days from start of the epidemic outbreak (which is different for every country, see red values in the last column of Table 2) to compare with the data set listed in Table 1. To increase the accuracy, we let this number to be non-integer. To calculate the corresponding time difference $d_{t}$, we use the parabolic interpolation for the initial number of cases $V$ in South Korea. The first three points in Table 1 yield the corresponding equation:

$$
V=a t^{2}+b t+51 ; \quad a=16.5, \quad b=36.5
$$

Then by putting into (1) the values $V=V_{b}$ for the number of cases at the starting day of the epidemic outbreak (shown in red in Table 2), the corresponding values $d_{t}$ were calculated for every country with the use of formula

$$
d_{t}=\frac{-b+\sqrt{b^{2}-4 a c}}{2 a} ; \quad c=51-V_{b}
$$

which yields a solution to the quadratic equation (1). The calculated values of $d_{t}$ are shown in the last row of Table 2 . Then the time moments for Italy have to be shifted by 0.549 days, for Germany by $6+0.154$ days and so on.

\section{Results and discussion}

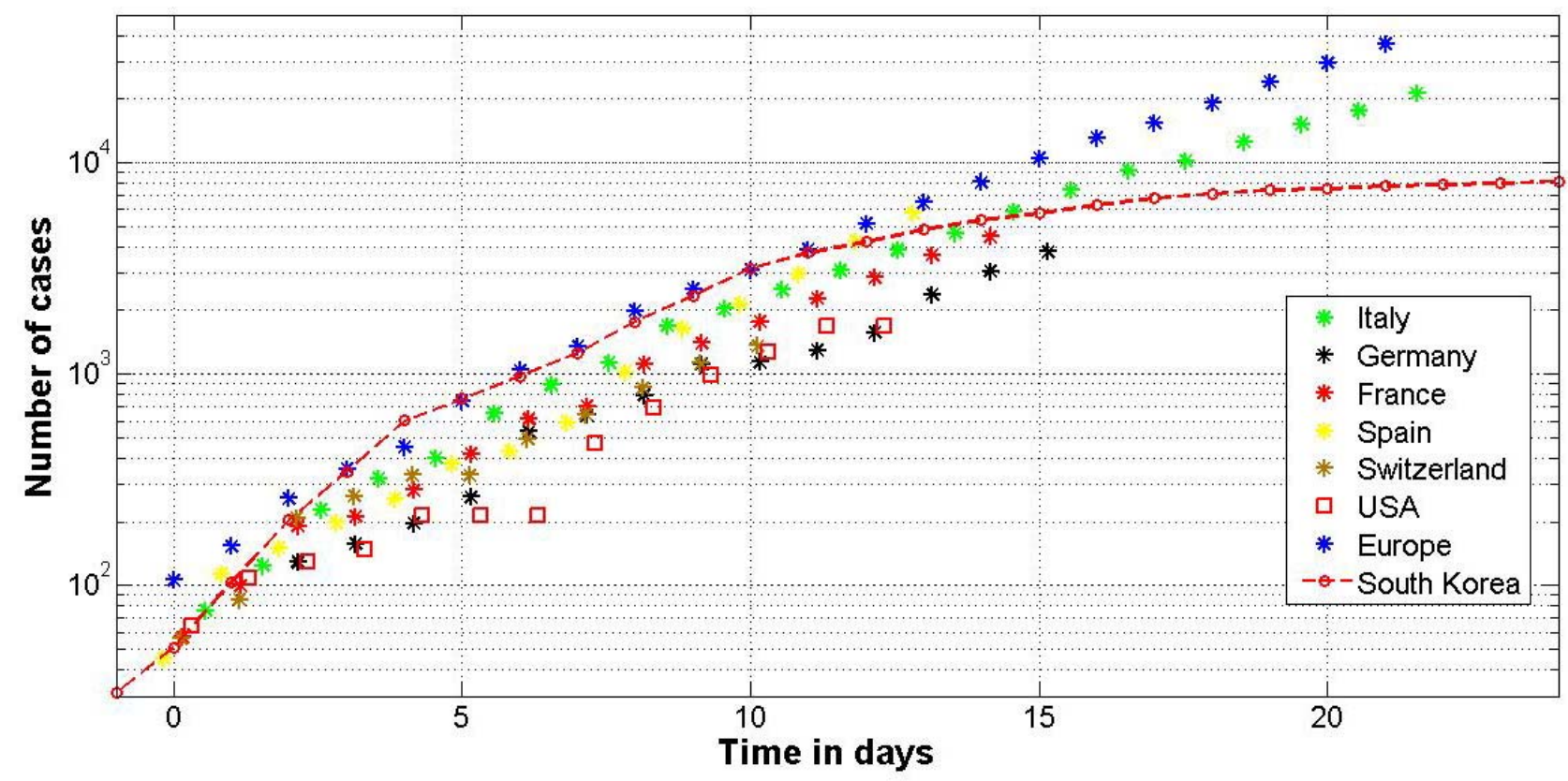

Fig. 1. The synchronized data sets for the accumulated confirmed number of cases versus time in days from the beginning of the epidemic outbreaks. 
medRxiv preprint doi: https://doi.org/10.1101/2020.03.18.20038133; this version posted March 20, 2020. The copyright holder for this

preprint (which was not certified by peer review) is the author/funder, who has granted medRxiv a license to display the preprint in

All rights reserved. No reuse allowed without permission.

The synchronized data sets are shown in the Fig. 1 by "stars" for countries in Europe and by "squares" for USA. The data for South Korea are shown by red line with "circles". Blue "stars" represent the sum of cases for 5 countries in Europe. It can be seen that Italy, Spain and France have no chance for rapid stabilization of the number of cases. But it is still possible in Germany, Switzerland and USA. Very high mortality rate in Italy and Spain makes the situation really dramatic. Blue "stars" in the Fig. 1 still follow the straight line. It means that the number of cases in Europe still increases exponentially and is far from stabilization.

It seems that main reason for the rapid increase in the number of cases in Italy and Spain is the slow isolation of infected and contact persons. For example, in South Korea an infected person spreads the infection approximately 4.3 hours (in average), [4]; the mortality rate is $0.92 \%$. By comparison, in mainland China this time is estimated as 2.5 days [5].

\section{How to estimate the epidemic dynamics for other countries?}

For example, let us illustrate the application of this simple procedure for Austria. The number of cases in this country was $V_{b}=66$ on March 6,2020. Let us suppose that epidemic in this country started on this day. Corresponding value of $t_{e j}=13$ (see Table 2) and $d_{t}=0.3542$ (according to eq. (2)). If we want to know how looks the situation on March 15, 2020 (ninth day of the epidemic), we open the corresponding WHO report (number 56) and find their the number 959 for Austria. This figure has to be compared with the number of cases from Table 1, corresponding to the time moment 9+0.3542. To avoid any additional calculations, let us take the value 2337 for comparison. Thus the situation in Austria does not look bad. This country is able to stabilize the number of cases soon.

\section{Conclusions}

The situation with the coronavirus pandemic in Europe is very threatening. Italy and Spain are in urgent need of assistance in speeding up the isolation of infected and contact persons.

\section{Acknowledgements}

I would like to express my sincere thanks to Ihor Kudybyn for his help in collecting and processing data.

\section{References}

1. Nesteruk, I. "How can we estimate the dangers of the coronavirus epidemic in Europe?" [Preprint.] ResearchGate. 2020 Feb. doi:10.13140/RG.2.2.32072.06402.

2. Nesteruk, I. "Comparison of the coronavirus epidemic dynamics in Italy and mainland China" [Preprint.] ResearchGate. 2020 March. doi:10.13140/RG.2.2.19152.87049. 
medRxiv preprint doi: https://doi.org/10.1101/2020.03.18.20038133; this version posted March 20, 2020. The copyright holder for this preprint (which was not certified by peer review) is the author/funder, who has granted medRxiv a license to display the preprint in perpetuity.

All rights reserved. No reuse allowed without permission.

3. World Health Organization. "Coronavirus disease (COVID-2019) situation reports". https://www.who.int/emergencies/diseases/novel-coronavirus-2019/situation-reports/. Retrieved Mar. 17, 2020.

4. Nesteruk, I. "Estimations of the coronavirus epidemic dynamics in South Korea with the use of SIR model” [Preprint.] ResearchGate. 2020 Mar. doi: 10.13140/RG.2.2.15489.40807.

5. Nesteruk, I. "Characteristics of coronavirus epidemic in mainland China estimated with the use of official data available after February 12, 2020." [Preprint.] ResearchGate. 2020 Mar. doi:10.13140/RG.2.2.19667.32804. 